\title{
Speech Etiquette in Online Communities: Medialinguistics Analysis ${ }^{1}$
}

\author{
Liliya Duskaeva \\ St.-Petersburg State University \\ St.-Petersburg, Russia
}

\begin{abstract}
The article deals with the peculiarities of communicative politeness in the poorly investigated sphere of Russian-language communication focusing specifically on online groups. The purpose of the article is to identify the ways and means used in this environment for the organization of polite communication. A distinctive feature of the author's research approach is the analysis of etiquette in the context of a dialogue, which means not only the analysis of the rules of stimulus, but also the rules of reaction, which corresponds to the systematic approach as a general principle of media linguistics (as a research method). The article defines speech etiquette as a system of norms and rules of polite speech behavior, the observance of which ensures the existence of the online community. The study allows us to conclude that the communicative tactics of etiquette in online groups are as follows: a) the participant's inclusion into the community is regulated; $b$ ) bans on some forms of speech behavior are established and sanctions for violations of bans are imposed; c) high communicative status is provided to the author in different ways and freedom for creative self-expression is guaranteed to each participant; d) on the one hand, the establishment of contacts with a partner suitable in one or another parameter is stimulated, on the other hand, the degree of the partners' proximity is regulated in accordance with the wish of its initiator; e) the opportunity to give/receive a response to a particular activity of the communication initiator is provided. These setups are implemented via a variety of resources, including both technical and speech means of address and response. Netiquette, drawings and images help to ensure emotional comfort. An adequate communicative distance is supported by abbreviations used in speech and understood only by the group members, by creating an adequate balance in the use of elevated and low stylistic means, in the use of methods creating a comic effect. Following speech etiquette rules is promoted by a kind of communication sanitation, which is carried out by the group administrator and the participants themselves. Participants use a metatext, which demonstrates the reflection of the group participants' speech activity. The existing rules in online communities are aimed at making communication emotionally comfortable, ensuring easy navigation, neutralization of aggression, and prevention of speech crimes, encouraging the users to demonstrate courtesy and display attention to one another.
\end{abstract}

Keywords: online community, speech etiquette, communication comfort, media linguistics, norms and rules of communication, communicative threats and risks

\section{For citation:}

Duskaeva, Liliya. 2020. Speech etiquette in online communities: Medialinguistics analysis. Russian Journal of Linguistics 24 (1). 56-79. DOI: 10.22363/2687-0088-2020-24-1-56-79.

\footnotetext{
${ }^{1}$ This work has been supported by RNF (grant 19-18-00530).
} 
Научная статья

\title{
Речевой этикет в онлайн-сообществах: медиалингвистический анализ
}

\author{
Л.Р. Дускаева \\ Санкт-Петербургский государственный университет \\ Санкт-Петербург, Россия
}

\begin{abstract}
Аннотация
В статье рассматриваются особенности вежливости в малоизученной сфере русскоязычного онлайн-общения. Цель статьи - выявить средства, используемые в онлайн-коммуникации для организации вежливого общения. Речевой этикет определяется как система норм и правил речевого поведения, соблюдение которых обеспечивает существование онлайн-сообщества, поскольку они направлены на создание эмоционального комфорта в общении, демонстрацию внимания друг к другу, обеспечение удобной навигации, проявление учтивости, нейтрализацию агрессивности. С этой целью в сети реализуются следующие коммуникативные тактики: а) регламентируется включение участника в комьюнити; б) оговаривается речевая форма авторского самовыражения, устанавливаются запреты на некоторые формы речевого поведения и налагаются санкции за нарушения запретов; в) автору обеспечивается высокий коммуникативный статус и каждому участнику - свобода для творческого самовыражения; г) стимулируется, с одной стороны, установление контактов с подходящим по тем или иным параметрам партнером, с другой стороны, регулируется степень близости партнеров в соответствии с пожеланием его инициатора; д) предоставляется возможность оставить/получить отклик на то или иное коммуникативное действие инициатора общения. Эти установки реализуются использованием множества ресурсов, среди которых как технические, так и речевые средства адресации и реагирования. Эмоциональный комфорт помогают обеспечить этикет, рисунки и фотоизображения. Адекватная коммуникативная дистанция поддерживается использованием в речи понятной лишь участникам группы аббревиации, созданием адекватного баланса возвышенных и сниженных стилистических средств, приемами создания комического. Исполнение речевого этикета поддерживается своего рода санацией коммуникации, которую осуществляют администратор группы и сами участники. Участники используют метатекст, отражающий рефлексию их речевой деятельности. Существующие правила в онлайн-сообществах направлены на то, чтобы сделать общение эмоционально комфортным, нейтрализовать агрессию, поощрять пользователей демонстрировать вежливость и проявлять внимание друг к другу.
\end{abstract}

Ключевые слова: онлайн-сообщество, речевой этикет, комфортность общения, медиалингвистика, нормы и правила общения, коммуникативные угрозы и риски

\section{Для цитирования:}

Duskaeva, Liliya. 2020. Speech etiquette in online communities: Medialinguistics analysis. Russian Journal of Linguistics 24 (1). 56-79. DOI: 10.22363/2687-0088-2020-24-1-56-79.

\section{Introduction}

The great variety and diversity of network communities or public groups of open and closed types spread on social networking platforms has formed new types of Russian-language communication in which text and audio-visual information is exchanged. Sociologists note that the novelty of those communities is defined by the following factors: they objectify flexible horizontal communication links which 
are characterized by voluntary participation, anonymity, the game nature of communicative roles, and virtual identification of partners ("friends") - which is often far from reality, and mediation (Boyd d., \& Heer, 20061, 2; Konchakovskiy, 2010; Pronkina, 2016; Sergodeev, 2014).

Many online communities organized in the network create their own speech etiquette (hereinafter SE) which, along with the generally recognized rules (=communicative values) of social speech behavior (and sometimes in contrast to them), are important for this particular social group. The study of speech etiquette in these communities will help to understand the nature of the connections established in them and answer many questions important for humanities. What communicative purpose (themes) unite the participants? In what communicative situations and how are the rules of interaction within the community expressed? What resources provide emotional comfort and efficiency to the participants of the interaction? Which of the newly formed norms of speech communication are embedded in the architecture of the existing rules of building relationships, and which contradict them? Finally, does the social structure of communication participants influence the rules of communication within the communities?

The need to answer these questions stimulates research interest in the speech practice of the communities united on different bases (on the bases of thematic, professional interests, social roles, etc.). Representatives of different research fields aimed at understanding the peculiarities of communication in different communities come to opposite conclusions. For example, sociologists argue that the rules "regulating the communication of community members through the mechanisms of cultural diffusion become almost the same for many typical groups" (Sergodeev, 8). The linguistic analysis which allows introducing the participants' speech behavior peculiarities into the sphere of visibility testifies to the differences in the rules (see, for example: Osetrova 2015). It becomes obvious that it is impossible to comprehend new forms of sociality in virtual reality when using only sociological analysis - the linguistic analysis of network communities' organization is necessary as it draws attention to the form of the participants' interaction.

Therefore, in order to understand how the rules of interaction in a community differ from the generally accepted ones and what is the relationship between the participants' social characteristics and the deviations from the generally accepted ones, it is necessary to identify those rules and resources for their implementation. The purpose of the paper is to establish the rules of speech interaction in online groups and the means by which they are implemented. To achieve the goal, we will try to answer a number of questions: a) what are the semantic and pragmatic coordinates of SE in social networks? b) in what situations do they manifest themselves? c) what are the speech markers of etiquette situations?

\section{Problem statement}

Studies of speech etiquette have been conducted for several decades; however, due to the extraordinary diversity of the speech etiquette phenomenon, there is no 
generally accepted definition of it in the modern linguistic literature: there are different ideas about semantic and pragmatic boundaries of SE and its linguistic markers in different languages.

In earlier linguistic studies, SE was seen as a set of stable, often formulaic and ritualized etiquette units and formulas, normative for communicants, assigned to stereotypical situations: "Greeting", "Acquaintance", "Farewell", "Apology", "Gratitude" and others (described in the following works: Akishina, Formanovskaya 1983; Coulmas 1981, 2005; Ferguson 1966; Goffman 1974; Goldin 1983; Kasper 1990, etc.), characteristic for interpersonal communication. In other words, speech etiquette is understood as the rules of communication formulas' use where the latter are nationally-specific, stereotyped, stable, adopted and prescribed by society to manifest the attention to the interlocutor and aiming to support a comfortable, relaxed atmosphere in the interaction.

Gradually, not only ritualized etiquette formulas have become the subject of SE linguistic research. In a number of works devoted to the peculiarities of everyday communication, authors began to talk about the scenarios of establishing communicative contact, its maintenance and interruption in accordance with the rules of social interaction that have developed in such cases: situations of formal/informal communication, gratitude, apology, leave-taking, etc. However, linguistic analysis of scenarios often focuses on vocabulary and phraseological units used in etiquette situations (Akishina, Formanovskaya 1983; Balakai 2004, Goldin 1983; Ferguson 1976; Kostomarov 1971etal).

The spread of pragmatics with its attention to the communicants' interaction expression has expanded the idea of SE in linguistics. The study of SE turned to larger units of its analyses in pragmatics, theory of speech acts, genre studies, units of a special group - etiquette speech genres, some of which became the objects of research (Blum-Kulka 1984; Duskaeva, Kornilova 2012; Olshtain 1984; Prokofyeva, Vasilieva 2016; Tarasenko 2002). With the transition to the study of speech etiquette genre design, its semantic and pragmatic boundaries have changed, since speech etiquette was now understood not only as the rules of using language manifestations of courtesy, but also as the rules of using linguistic and non-linguistic means characterizing the emotional attitude to the addressee, as well as the distance between communicators. With the introduction of the concept of politeness into linguistics and the establishment of the principles of politeness (Brown and Levinson, 1987), it became possible to correlate this property with the manifestation of speech etiquette. The latter began to be seen as a compliance with the rules of decency, courtesy in speech, communication harmonization manifested in the use of speech interaction forms in accordance with certain situations, as well as with gender, age, degree of kinship and acquaintance between the participants of communication. Thus, the rules of harmonization began to correlate with the speech etiquette manifestation.

Some researchers argue that "the widely accepted interpretation of etiquette forms as forms of politeness" is wrong (Khrakovskiy, Volodin 1986, 224), "the 
expression of politeness and etiquette in language... must be differentiated" (Alpatov 2018, 7). Khrakovskiy and Volodin (1986, p. 224) write: "According to the existing dictionary interpretations, politeness is explained as courtesy or civility. When observing the rules of speech etiquette, we are usually not courteous and kind on purpose; we are neutral in this respect and cannot behave otherwise in a situation when we are forced to choose one of the forms of address... Nonetheless, language can express a polite speaker's attitude to the listener... regardless of the interlocutors' social status". They conclude that the researchers rely on imperative forms' expression for etiquette purposes. However, the subsequent study of SE as a system of forms refutes this statement. Thus, according to Larina, politeness in the Russian language "is compliance with the rules of conduct (not to violate means to observe)" (Larina 2009, 137). The researcher refers to the data of the Russian language dictionaries, in which polite is defined as 'observing the rules of decency; courteous'. Larina emphasizes the differences in understanding politeness in different cultures: the English believe that to be polite means to show respect and attention to others, whereas Russians think it means to know and follow the rules of conduct (Ibid, 141), "Russians prefer sincere and informative behaviour rather than manners and tact" (Larina 2015: 196). Our data confirm these conclusions.

In situations of online communication, the user faces a choice - to employ or not employ etiquette forms the use of which is considered to be a manifestation of politeness. It seems natural that the concept of speech etiquette is gradually expanding in Russian and foreign linguistic research: the rules of speech behavior include not only stable formulas, but also compliance with the principles, postulates and maxims of speech behavior, which provides for a comfortable flow of communication, relieves tension in relations between communicators and makes communication effective (Grice 1975; Formanovskaya 2015; Held 2005; Kaspe, 1990; KerbratOrecchion, 2006; Lacoff 1973; Leech 1983; Loc her 2004; Risinzon 2010; Sifianou 1999). Studies of SE as a means of harmonization in everyday spheres (Akishina, Formanovskaya 1983), diplomatic (Ratmair 2009), business (Cubajevaite, Ruzaite 2007) have shown that the means and methods for courtesy expression in different spheres of communication may vary. In this regard, there is a need for a differentiated study of SE depending on communication spheres, including media (Ermakova 2000; Duskaeva 2018; Pakhomova 2008; Risinzon 2010). This problem statement requires defining the SE concept in its relation to every other sphere.

\section{Definition of SE in online communities}

Despite the breadth of researchers' interest in certain aspects of speech etiquette in communicative practice, the problem of the definition of SE is far from being solved. The problem of a systematic integrated approach developing for its analysis remains open, too. The question of speech etiquette in online communities is becoming part of a broader and more urgent problem of individual communicative behavior in a virtual environment. The questions about the communicative boundaries of the personal and public spheres, about the admissibility and inadmissibility 
of discussing intimate details in the public space of communities were analyzed. The use of spoken vocabulary, and slang in particular, is seen as a reflection of distance convergence between communicators (Kornilova, Vasilieva 2015; Ermakova 2000). In some communities, the lack of novelty in messages is regarded as a violation of speech etiquette (Osetrova 2015).

Considering the nature of communication links between the participants, researchers raise the question about the transformation of the universal concept "friendship" in the network community (Boyd, d., \&Heer J. 20062). In particular, it was found that the concepts "friend" and "friendship" in virtual communication acquire a different connotation, serving only to establish communication links between the participants. This meaning is, in fact, synonymous with the term "link", which is used in network analysis. When a person has hundreds of "friends" on the Internet, the mutual emotional component of the concept is distorted. The concept of "friendship" has little in common with the original meaning of the word; it becomes less significant and more technological (Boyd 20061).

Compliance with speech etiquette is one of the most important factors in the successful achievement of communicative goals in online communication. Before taking part in group communication, future participants gets acquainted with the general rules of communication in the group and then act according to them. Familiarity with the features of online communication shows that it is more conventional than direct communication, during which communicators always have the opportunity to adjust their behaviour. Conventions within communities are established in accordance with the proclaimed communicative values. Turning to the practice of organizing interaction in groups, we find that the administrator usually outlines and details the rules of speech behavior for group members on the main page of the community. Judging by the results of the analysis, we can speak about the formation of a special type of text - "Warning of the administrator-initiator addressing the community members", which aims to set out the speech etiquette for the group and at the same time to demonstrate the rules of speech interaction accepted in the community.

The text type tends to include a statement of the rules of communication in the group, including: prohibitions concerning certain forms of verbal behavior and certain actions of speech, restrictions concerning individual speech acts, and the imposition of sanctions for violations of the community speech etiquette. The set of rules makes it clear what communicative values the communication is based on. Familiarity with the rules of group communication set out by community administrators, contributes to the reconstruction of communicative intentions in the user's speech activity associated with compliance with the speech etiquette rules. The first part of the text type is, as a rule, a thematic group's presentation: 1) "Dear friends, members and participants, our Group is created for the thematic friendly communication. Please, observe the rules of network etiquette to avoid misunderstanding!" (from the rules, "Leonardo, dai vinchik!" — https://vk.com/topic-33158301 27022648). Uniting the participants on the basis of the theme and friendly 
participation is declared as the goal of the group, while compliance with the network etiquette rules is a condition of successful existence in it. The examples show that the preservation of thematic unity in the online communities' speech interaction is their communicative value, and a task of all participants is to sustain it. The thematic unity is required in the rules of many groups: (1) When uploading photos - follow the album's theme (from the rules, "Leonardo, dai vinchik!"); 2) itmis prohibited to discuss third-party topics or issues not related to the group's topic, other resources, media or events. Another communicative value is friendliness in communication (in the rules it is stipulated as follows: (2) Thank you in advance for your understanding and desire to make our group more polite and friendly (from the rules of the tattoo community).

The requirement is expressed with requests: (1) ... follow the theme of the album; 2) Don't be rude, if criticized; with warnings: If you post a photo of your tattoo or its preliminary sketch get ready for criticism; with prescription of actions: Queries with questions and requests to rate this tattoo are to be republished on behalf of the group with the mark of the author; The requests that have been met, are immediately removed; with the rationale for the prescription (for example, the promise of "benefit" which the recipient will receive following the norms of communicative behavior, with the construction of the future tense: so your request will be visible to the majority of participants, you will get more answers or ratings; or with a subordinate clause of purpose: not to clog the wall).

The rules also introduce a ban on certain speech actions: it is forbidden to post links to groups in comments to photos; spam and flood are prohibited; advertising of any goods and services, appeals to "put heart-emojis", to join in certain communities, to vote for someone in the contests, and other messages which can be generally perceived as "spam" are prohibited; on certain forms of verbal behavior: trolling, flame (conflict provoke) and curse words are prohibited; overt and covert brutality, rudeness, insults, personal claims, altercation, discussion of personal qualities of any of the forum participants are prohibited; on some types of meaningful statements: It is forbidden to insult others on the basis of ethnicity; Advertising and links to third-party groups is prohibited, advertising can only be placed under the title "Your advertising" https://vk.com/topic-37497136_28208666; racism, religious and political statements, discussion of non-related topics or issues not related to the group's topic, other resources, media or events are prohibited.

The prohibitions set out in the rules are, among other things, a declaration of the group's values. As we can see from the examples above, administrators announce the unity of the theme, ease of communication, and emotional comfort. The prohibited disorganization of posted messages and spam bring inconvenience. Deviation from the topic announced in the group as the primary rule or diverting the conversation to the political sphere makes it difficult to maintain interest in the conversation. Aggressiveness breaks emotional stability and can potentially provoke speech crimes for which the group will be closed and the administrator will be punished. 
To protect values, sanctions are imposed for different types of communication violations: The site administration reserves the right to delete comments or parts of comments if they do not meet these requirements. If you violate the rules, you may be given a warning. In some cases, you may be banned without warning. You should write to the administrator about lifting bans. Insulting administrators or moderators is also punished with a ban - respect other people's work (https://vk.com/pages?oid $=17605759 \& \mathrm{p}=\% \mathrm{CF} \% \mathrm{D} 0 \% \mathrm{C} 0 \% \mathrm{C} 2 \% \mathrm{C} 8 \% \mathrm{CB} \% \mathrm{C} 0+\%$ $\mathrm{CE} \% \mathrm{C} 1 \% \mathrm{D} 9 \% \mathrm{C} 5 \% \mathrm{CD} \% \mathrm{C} 8 \% \mathrm{DF}+\% \mathrm{C} 2+\% \mathrm{C} 3 \% \mathrm{D} 0 \% \mathrm{D} 3 \% \mathrm{CF} \% \mathrm{CF} \% \mathrm{C} 5)$. For the presentation of sanctions, two types of structures are important: 1) those explaining the conditions of their imposition - a prepositional-nominal form (in violation of the rules) or a conditional subordinate clause (if they do not meet these requirements); 2) those describing the sanctions (reserves the right to delete comments or part of the comments; a warning can be given; are punished with a ban). Following the rules helps to prevent speech disorders in advance and to warn against committing speech crimes.

The rules of speech etiquette are necessary for the formation of online communities: they contribute to the internal organization of the community. On the one hand, following the rules provides for the possibility of each community member's active self-presentation; on the other hand, the rules ensure the stability of interpersonal communication links. The participant's situational communicative intentions include: informing (notifying, training, instructing) or phatic (game), supporting communicative connection with other participants by means of comic. The realization of these goals is valuable for communicants.

We can conclude that speech etiquette in online groups is a system of verbal and non-verbal resources, the use of which in dialogical communication allows participants to maintain comfortable involvement in communication as they contribute to the achievement of the following tasks: a) regulation of the participant's inclusion in the communication environment; b) conventionalization of the speech form of the author's self-expression, prohibition of some forms of speech behavior and imposing sanctions for the violations of those prohibitions; c) preservation of the author's high communicative status in different ways and providing each participant admitted to communication with freedom for creative self-expression; d) on the one hand, stimulation of contact establishment with suitable partners according to different criteria; on the other hand, regulation of contact proximity with them according to the wish of its initiator; e) providing an opportunity to give/receive different forms of response to a particular activity of the communication initiator; $f$ ) the indication of the behavior deviance, restrictions on deviations from the speech behavior rules existing in the networked society, until the records are removed. Therefore, in order to comply with SE in social networks, it is important to maintain communicative values shared by the whole community during the entire interaction; to detect communication threats in time and neutralize them with condemnation or even imposition of sanctions.

Linguistic analysis of speech etiquette involves the identification of the characteristics of communicative relations between the online communities' 
participants and their linguistic indicators established by the rules. To analyze verbal interaction in online groups, we used the metalinguistic axiological method the peculiarities of which are discussed below.

\section{Methods of Data Analysis}

To characterize the set of communicative rules between group participants and identify their linguistic features, we used the metalinguistic praxeological method which helps to investigate the dynamics of speech activity deployment in different spheres of communication (Duskaeva 2018). The praxeological method includes several research operations: 1) development of functional-semantic typology of statements, 2) disclosure of linguacompositional properties of communicative actions in each type, 3) critical analysis of the selected form while checking whether it complies with the rules of comfortable communication.

The first research operation is the development of functional-semantic typology of statements. It is carried out through a consistent reconstruction of the participants' communicative intentions associated with the compliance with the rules of speech behavior in the network. At this stage, the typical ways of the compositional organization of statements are revealed as social and communicative actions carried out in the sequence of speech. Taking into account the dialogical nature of communication in the group, it was expedient to highlight the sequence of situations in which the group communication plot develops. The first situation is the initiation of two types of contact: a) invitation to participate in the group, b) speech stimulation; the second scenario is the continuation of the contact (speech reactions); the third situation is the presentation of communicative rules; the fourth is the reaction to a communicative provocation or violation of communicative rules.

When inviting individuals to participate in the group, i. e. initiating communication, administrators introduce the rules of speech activity (theme and form of contact). The administrator-initiated warning addressed to the community members is intended to prevent the group members' speech misconduct. As it was determined in the analyses of SE in group communication in nets, such a "warning" sets out prohibitions on certain topics, imposes restrictions on certain speech actions, and informs about sanctions for community speech etiquette violations. Contact is stimulated by giving participants the opportunity to express their communicative interests. In the subsequent speech response, stress relievers are used.

When performing the second research operation, the focus is on the stylistic analysis of statements in order to reveal the means of implementing communicative goals. The analysis of the organization of speech communication reveals the means of contact initiation and response, emotiveness, expression of communication evaluation, identifies violations of the etiquette and use of verbal sanctions. At this stage, the typical ways of compositional organization of statements as social and communicative actions are revealed in the sequence of speech. Attention to the system of separate resources used in the course of interaction to achieve communicative comfort makes it possible to reveal the "anatomy" of the speech activity 
harmonization; its main feature is the research interest in the role of individual linguistic and non-linguistic means in their etiquette expression.

It is important to understand that the speech etiquette of online communities includes the rules of using not only verbal means but also non-verbal signs of netiquette: signals, indices and symbols among them. Comfort in online communication is created with signals that are signs of warning, indexes or symbols - signs that do not only indicate an object but also have an additional modal meaning: they express general ideas and concepts related to the interpretation of the object, express the attitude to communication and to the recipient (Brief Encyclopedia of Symbols).

The third research operation is a detailed critical analysis of the SE resources determined on the second research stage. It shows which means make communication comfortable or, conversely, create discomfort. To see the "work" of etiquette resources maintaining the high status of both the communication initiator and the recipient, it is expedient to analyze the use of etiquette tools in the dialogue through a sequence of speech interactions.

This four-part structure of media-linguistic analysis allows us to study the SE inside the speech activity as tools, techniques and ways of harmonization that develop the "plot" of communication, accompany speech interaction, make it comfortable, and relieve stress. The four approaches interact and gradually reveal different sides of speech etiquette in communities.

\section{Material Analysis}

The major material of our analysis was the speech practice of two network Russian-speaking groups. The first group "Ask the Experienced Ones" is localized on the site "Country of Moms" (https://www.stranamam.ru/post/14016040/)"; its participants are women who are looking for answers to their family life everyday questions in group communication. The structure of dialogical communication consists of the interaction: "Request for advice - Advice of the experienced users". The second group is "Leonardo, Dai Vinchik!" in the social network Vkontakte (https://vk.com/dayvinchik). Its participants, as it can be seen from the name (the wordplay is that Da Vinci sounds similar to the phrase 'give some wine' in Russian. - Translator's remark), have fun placing something remarkable for communicants posts, images with inscriptions, quotes of famous people, tips and comments in common chats. The analysis of speech used in the two groups will be supplemented by the material from other communities to demonstrate the overall picture.

Earlier we discussed the compositional and linguistic expressions of warning the participants about the rules of group communication, i. e. presentation of communicative rules. We further, distinguished the means which initiate contact and response, emotiveness, expression of connotations, identified violations of etiquette and the use of verbal sanctions. Below, stage by stage, we show SE resources accompanying intragroup communication in its basic communicative situations:

I. Initiation of contact: a) invitation to the group, b) communication stimulation. 
II. Continuation of contact (speech reaction).

III. Communication rules' presentation.

IV. Reactions to communicative provocation or violation of the communication rules.

\section{Initiation of contact}

a) Invitation to the group. Here are some examples.

Group "Ask the Experienced Ones"

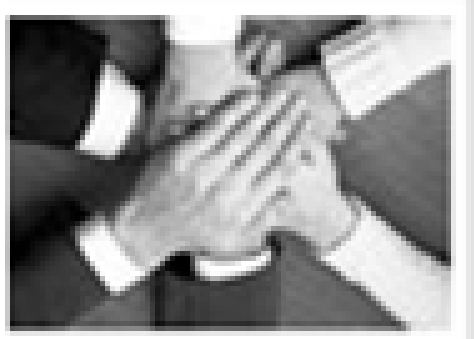

Picture 1

If you found yourself in a problematic situation and just don't know what to do, ask us, the experienced ones...We will always understand, support, and give a hand. Advice on any life situations concerning our families, husbands, children and ourselves))

Group “Leonardo, Dai Vinchik!”

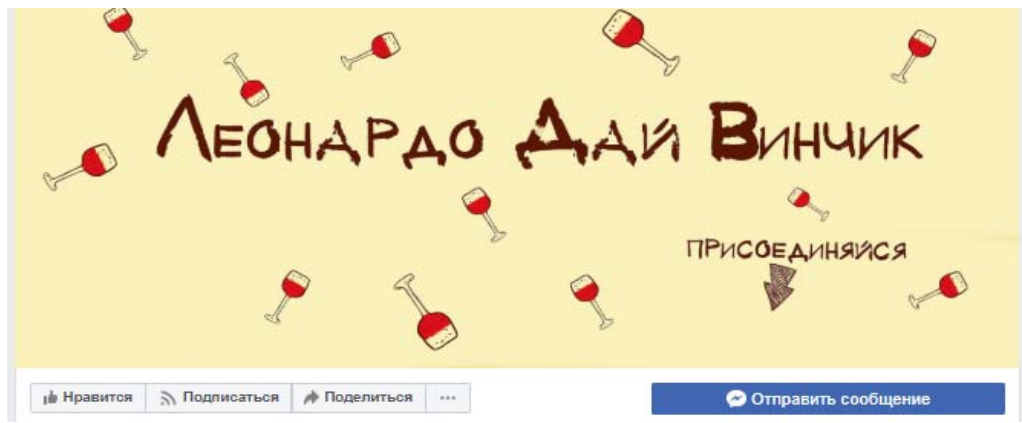

Picture 2

Join us at

Like, Subscribe, Share Send a message

As we can see, the communicative action of invitation in those communities has three components: first, it defines the rules of the group (in particular, sets out the rules of initiation of communication); second, it advertises communication in the group; and third, the reader is encouraged to get involved in emotional and speech activity. The possible reasons for communication contacts may be information-oriented ("if you are in a problematic situation") or based on wordplay 
("Leonardo, Dai Vinchik!'). In the first fragment, the situation is described directly; the invitation uses a picture of hands placed on one another, which symbolizes the willingness to help members of the group. In the second fragment the situation is described indirectly: with a playful, even dismissive reformulating of the brilliant Renaissance artist's name, Leonardo da Vinci with funny glasses filled with red wine at the background (wine used as a symbol of happy life filled with joy and pleasure; wine for creators - a source of inspiration (cf.: Good wine makes thoughts quicker in a song by Y. Kokhanovkiy or Wine makes wit wittier ("Date with a countrywoman" by P. Zbylitovskiy cited by: Brief Encyclopedia of Symbols; internet resource).

It's important to note that there are other groups in Runet the names of which are based on word play reformulating famous people's names: Grigory Schwepps (instead of Grigory Leps), Salvador v Dali (instead of Salvador Dali), IPhone (instead of Anton) Pavlovich Chekhov, Molbert (instead of Albert) Einstein, Robot (instead of Robert) De Niro, Sylvester v stolovoy (in the canteen) (instead of Stallone). The word play is based on "homophone fun" using the names of famous people: artists, actors, singers, writers, and scientists.

The urge for emotional and speech activity is expressed both directly and indirectly. In the first case, directly - with a causative form of the verb ask us and indirectly - offer to give advice on any life situations; in the second case, directly — with the incentive join, and indirectly — by providing opportunities for the addressee to approve something (Like) or engage in communication (Subscribe, Share or Send a message), or demonstrating consolidation in the group with clicks. It also sets out the rules of the group organization - everyone can join the group.

In the network invitation there is no traditional Russian address by name because its recipient is not defined - it could be anyone. Politeness is manifested in addressing the recipient (in the plural you got, you do not know, ask how, join,), in guaranteeing attention to the addressee's state (we'll understand, support and gave a hand), to his attitude to the subject of conversation (like, share).

Advertising of the group is carried out either directly, by naming its advantages (experienced, advice on any life situations concerning our children, husbands, families and ourselves), in the identification of themselves with a potential interlocutor (expressed in the use of the pronouns our and $u s$ ), in a direct call (join) or indirect motivation (created by the image of wine glasses scattered at the background).

b) Communicative stimulation. At this stage, the author expresses his/her communicative interests.

In "Ask the Experienced Ones" group, initiation is transmitted with (a) a question or (b) a request for help:

а) Девочки, всем привет! Моя хорошая знакомая ждет малыша. Скоро встанет вопрос о покупке коляски. Живет она в квартире на 2 этаже. Нужна будет коляска, которая сможет «шагать» по ступенькам, т.к. лифта нет, а внизу коляску оставлять нет возможности. А еще знакомой предстоит пкс, значит тяжелое нельзя поднимать. Подскажите, 
пожалуйста, какие колеса у коляски должны быть, чтобы ее можно было спустить/поднять по лестнице: 1) большие, как здесь: (фото) 2. Или средние, как здесь: (фото). Источник: Страна мам. https://www.stranamam.ru/post/14032800/

Which wheels can "step" on the stairs?

Girls, hi everyone! A good friend of mine is expecting a baby. Naturally, she's going to buy a pram. She lives in a flat on the second floor. She'll need a pram which can "step" on the stairs as there is neither a lift nor a possibility to leave the pram downstairs. She's going to undergo a Caesarian and won't be able to lift heavy weights. Please advise what kind of wheels the pram should have so that it could be driven up and down the stairs:

1. Big ones, like here:

2. Or medium size, like here:

\section{Поймать воришку}

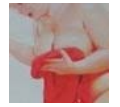

\section{$\underline{\text { s evgeniya }}$}

Добрый день! Нужна помощь в выборе камеры видео наблюдения или датчиках движения. Завелся у нас воришка, предполагаю кто, но поймать не могу. Поэтому есть цель поставить какое-то устройство, для ловли с поличным. В специфике такой техники не разбираюсь, от слова совсем. Стоять будет в деревне на улице. И да я понимаю чем дороже тем лучше и надежнее, но не хотелось бы сильно тратится на это. Может есть что бюджетное? И что стоит у вас и ваших друзей, знакомых?

To catch a thief

b) Hello! I need help with choosing a CCTV camera or motion sensors. We've got a thief, I suspect who it is but I can't catch him. Therefore, there is a plan to install some device to catch him red-handed. I do not understand the specifics of such equipment, no idea at all. It's going to be placed in the village outside. And yes, I do understand, the more expensive a device, the better and more reliable it is. But I would not like to spend a lot of money on it. Is there anything inexpensive? Something you and your friends have dealt with?

It is important for the author to specify the "subject" in a special window, to simplify the communication, the purpose for seeking advice, for example, (a) in the form of a question (Which wheels can "step" on the stairs?) or (b) as a "task" (To catch a thief). Both in examples (a) and (b), the initiators use nicknames (MarM, s evgeniya), which is allowed by the group rules. Then, greeting all those who are willing to respond, they encourage them to take part in the discussion: in (a) by means of using an intimate address (the diminutive ( $\mathrm{Girls}$ ) and the $(\mathrm{Hi})$. In (b) the appeal to the generalized addressee with a neutral greeting (Hello!) doesn't create this communicants-uniting effect. The invitation form already sets the distance between the participants. In the first case it is "shorter". 
The reason of initiation comes next - a problem situation in which the author of the post appears and the question is formulated in (a) fragment, with the demonstration of photos (big and average wheels of a baby pram) expressing a request for advice, in (b) fragment - a need for advice (I need help) is stated.

The politeness of the communicative situation initiator is expressed in the greeting of the addressee, in the manifestation of interest for another person: the speech appeals to him/her, in the justification of the request, in an effort to prevent possible questions:

I do not understand the specifics of such equipment, no idea at all. It's going to be placed in the village outside. And yes, I do understand, the more expensive a device, the better and more reliable it is. But I would not like to spend a lot of money on it.

Initiation of conversation in "Leonardo, Dai Vinchik!" group VKontakte is a post that sets the topic that subscribers are invited to discuss. This creates "live" communication, which involves a great number of participants. It is important to choose a topic to arouse the interest of many people. Particularly active chats happen before weekends when followers have more free time. Most often posts include a "picture" - a photo or a hand-drawn image with a signature, for example:

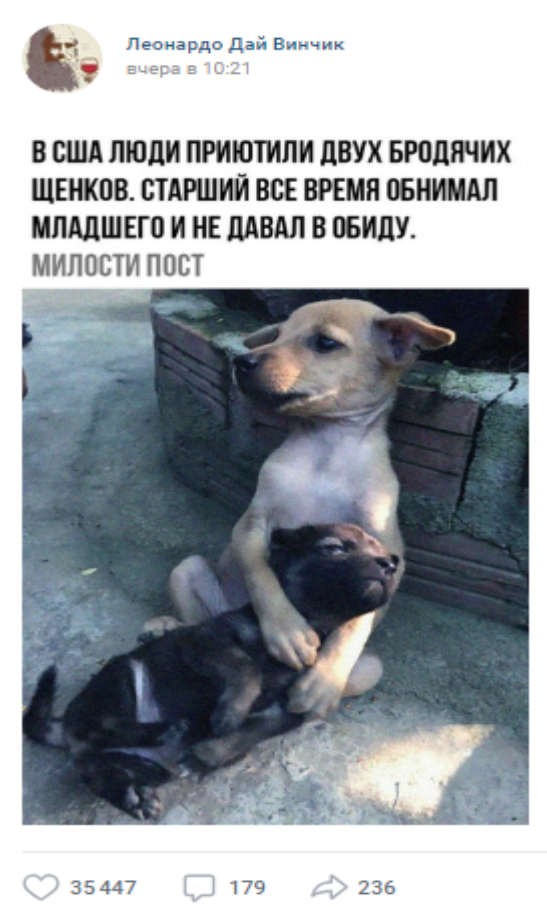

Picture 4. In the US people gave shelter to two homeless puppies.

The older one was hugging and protecting the younger one all the time. A post of mercy

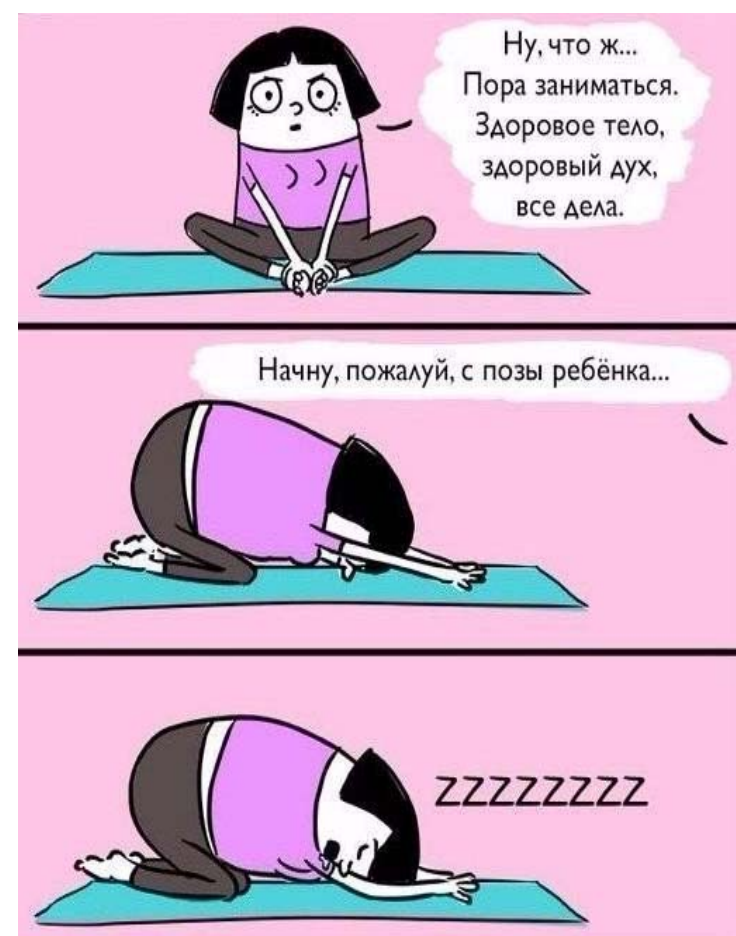

Picture 5. Well...It's time to do some exercise. A healthy body makes a healthy spirit, things like that. I'd rather start with a "baby" position...ZZZZZ 
To maintain long-term communication, it is important to choose a topic that will interest many people: "touching", funny, making them smile or laugh — this is what can attract a large number of participants. On the one hand, initiation of communication without the ability to attract others' attention is doomed to failure. On the other hand, the fact that initiators sometimes pass all boundaries of what is permitted and lose their independence in the pursuit of likes cannot be approved.

In the examples above, the basis of initiation is the image. In the first case, the photo is touching and has an emotional effect on the audience: it is about the kindness of the animal which manifested the ability to take care of the younger and defenseless one. It goes without saying the post awakens "good feelings" - mercy towards the weak and defenseless. The photo shows a small dog hugging a younger one, covering it with a paw. The audience perceives this older's embracing gesture as patronizing and protective. This is confirmed by the text accompanying the photo signature: ... people gave shelter to two homeless puppies. The older was hugging and protecting the younger one all the time. The inscription merely comments on the photo stating the place of the event (the US) where the abandoned puppies found owners. The post gathered over 35 thousand likes and 236 comments, which is a lot for the group.

The second image is a set of successive cartoons - a female with rounded forms wearing sports clothes on a sports mat. In the first picture it is ready to start exercising, in the second - inclined to the floor, and in the third - asleep. The artist makes a joke of common situation where the intention to carry out the doctors' instructions to exercise "falls asleep" before we even start doing it. This post also caused an active communicative response.

It turns out that witty posts that cause good feelings and pleasure are the most approved ones.

II. Speech response. In the course of response, different participants formulate tips, hints, and humorous comments as a response to the tips themselves:

1) in the group "Ask the Experienced Ones"

(a) reaction to the question about a pram:

- The larger the wheels are, the easier it is to drive it down/up the stairs. Inflatable wheels are better than cast ones. Well, that's my personal experience.

- Thank you!

- With a seam I would walk the babyon the balcony only.

- Of course, if the baby doesn't mind. There are babies who sleep only while outside.

- You're right here-my daughter slept only in movement-a stop-here you are-eyes open. It was a challenge for the dad — with our first baby he used to sit on the bench with a magazine.

- Yes, I heard such stories from other moms. You're lucky with your dad

- Out dad got into good hands. We made him a responsible dad and discovered many other useful talents in him. 
- Until lifting weight is allowed again, any "wheels" are out of the question. Dragging the pram up and down the stairs is going to be a burden on the stomach. She'll need help with this anyway. If alone, outside sessions should really be limited to the balcony.

b) situation with catching a thief:

- Look at Ezviz. The camera also needs to be electrified and to be recording information. Outside means where exactly? It will get wet under the cover anyway.

- Thanks, I will look at this brand. It will be hanging under the awning. What electricity do you mean? It's available. It can use the battery from a tractor, too.

- You need a special power supply, I'm not sure about the tractor battery...we use small ones. I can write to you tomorrow personally describing the system in detail, my husband knows about them but it's not a cheap variant anyway...There are also cameras you can talk to your thief through...if there is an internet connection.

—I only need to catch him at the place. The police will talk to him later. Please, write to me personally if you can.

As is seen from above, the politeness of the speech initiator is manifested in the expression of gratitude for the initiator's response to his request and in signs of attention to the tips acquired from others.

Courtesy of the authors of the responses (advice) is manifested in the attention to the questions. Giving advice, they act prudently and seek to ensure that their advice is appropriate. Since they take into account the conditions in which the conversation initiator appeared, their answers contain repetitions of words and combinations containing the description of the problematic situation: (the first participant) With a seam I would walk the baby on the balcony only Of course, if the baby doesn't mind. There are babies who sleep only while outside. Until lifting weight is allowed again, any "wheels" are out of the question.

However, deviations from the topic are also possible and quite acceptable here, since communication takes place outside the zone of interlocutors' visibility, i. e. indirectly. In the course of responding to requests, participants of group communication can make extra humorous comments sharing their life experiences. The humorous tone is characterized by the use of special markers - a variety of emoticons that complement the picture of the author's emotional dynamics. It seems that, giving comments, the author is having fun him/herself and entertaining the audience.

III. Reaction to a communicative provocation or violation of the rules of communication

Either the administrator or the communication participants apply sanctions in a group conversation. As we have already noted, the rules of communication in the group are formulated on the main page of the community, as it is necessary for the group organization. The formulation of such rules is dictated by the need to comply with Russian legislation which prohibits propaganda of nationalism, xenophobia 
and extremism in the networks. Acute public criticism of the speech quality of Runet content forces community organizers to impose speech sanctions for malicious violators of public speech behavior rules. To eliminate or neutralize aggression in communication, different ways are used.

Communication participants often diagnose the quality of other people's speech activity pointing to the violations of the rules. Computer jargon formed a whole lexical and semantic field, the components of which mark speech disorders: flood, ban, trolling, bashing, flame, spam. The initiators of such behavior are called by means of words with the same-roots: flooder, troll, hyperi, bot, bayan, flamer, spammer, etc. Here are examples of some of these words: Elya, first, in the post above we wrote about the prohibition of 'sofa' expertise and other bashing, which gives nothing useful in search of the girl. Second, if you do not know what to do in such situations, ask the police or Lisa Alert for instructions (Jubileyniy district and Shuvalovskiy - an example of Y. M. Konyaeva); from the communication in other groups: Mais, nobody is giving likes... you wanted to hypenate right? If you wanted to hypenate on the famous group then congratulations, you got it, but in what a nasty way!!!! Alice, we're sick and tired of bots in the comments, ... now I only see downs who write ... off-topic. Stupid bots, die; Sergey, ban ('Leonardo, Dai Vinchik'). Using these comments, communicants themselves manage the interaction seeking to exclude verbal actions that violate the etiquette. The same effect is achieved by negative responses to stimulating remarks or, for example: Gerechterweise: it is a pity we can't express dislike (Leonardo, Dai Vinchik). Rinat Lyubovny has been repeatedly complaining from 13-02 to 15-40 to the members of the group on the low quality posts: Why me? Where are those shameful posts from?.. God, why did I even watch this stupid post!.. Guys, tell moders, to give us normal posts, not "this" (Leonardo, Dai Vinchik!) This opinion collected a large number of likes. Such language means "bring together" certain people and alienate "strangers".

The use of occasionalisms, specialized jargon words or abbreviations usually known to frequent visitors of the communities allows some members of the group to adjust the degree of the set contact closeness with others: to rofl, rofles (abbreviation from the English "Rolling on the floor laughing"), moders (a shortening of moderator), dislike, muzlo (a rude shortening of music), chicksa (a girl), BDSM, ls (personal messages), etc., for example: rofls at teachers, the best muslo is here, a wow chicksa (Leonardo, Dai Vinchik). In this group, constructions characteristic of spontaneous, unprepared speech are often used in the comments (which is discontinuous, without a stable chain of connection, as well as much obscene vocabulary.

The group members are sanctioned for the use of individual speech actions that seem unacceptable to the administrator. In case the rules are violated, the group administrator intervenes: he/she removes statements containing obscene expressions or inappropriate ridicule. In "Leonardo, Dai Vinchik!" group you can find an inscription in the comments, which indicates that the administrator monitors compliance with the group rules, in one way or another: "The comment was deleted by the user or the page administrator." Different speech actions, such as advertising, 
are subject to regulation. According to the rules of "Our home - Nevsky district" communication group (example by K. Pusurmanova): Advertising and links to third-party groups are prohibited; advertising can only be placed in the subject "Your advertisements" https://vk.com/topic-37497136_28208666. If you want your advertising on the wall, please, contact the administrator, Anastasia https://vk.com/id3974480.

In groups that are organized out of the leisure sphere, there are stricter rules for the organization of communication. For example, in the "Friends banks.ru" group there is a special function of the site as a form of sanction, which is imposed on those who give inaccurate information in the reviews: In ignore and further for statistics you are ignored. In case of incorrect placement of the participant's comments, he/she receives warnings:

Picture 6.

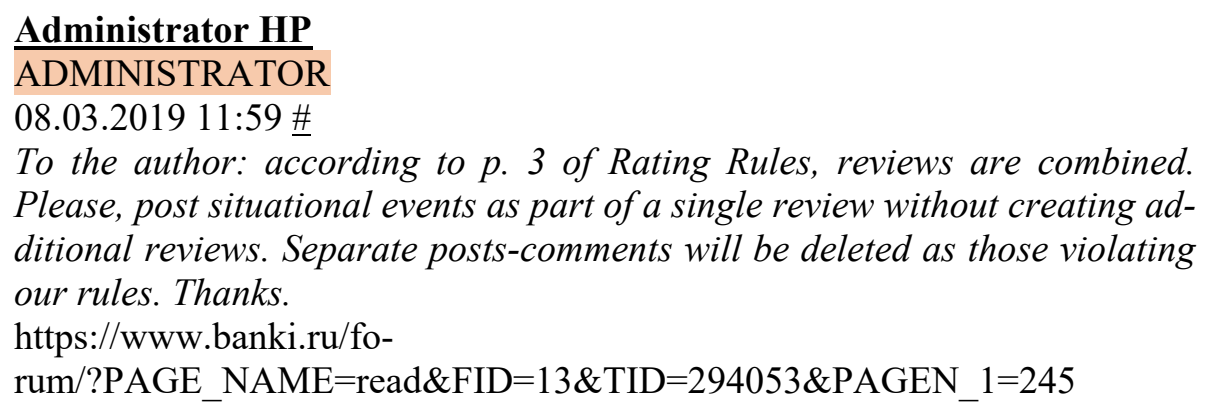

As you can see, in groups whose goal is to get reliable information about someone's activities in the financial sphere, the correct placement of one's comments is a condition of communication politeness.

\section{Discussion of the results of speech material analysis}

Speech etiquette in Internet communities is a set of speech norms, rules and principles that determine the selection and use of speech and non-language techniques and tools in the dialogue. They contribute to the preservation of effective successful interaction. Communication in the network community is governed by the SE rules, which guarantee the participant's inclusion into the communication environment; speech form of author's self-expression, prohibitions on certain forms of speech behavior and the imposition of sanctions for violations of these prohibitions. This policy is to ensure that everyone admitted to the communication are free to express themselves creatively, stimulate, on the one hand, the establishment of contacts with a partner suitable according to some parameters, regulate the degree of communication convergence in accordance with its initiator's wish, provide opportunities in different forms to leave/get a response to a particular activity of the communication initiator, as well as to prevent deviations from the existing rules of speech behavior in the network community. Compliance with these rules ensures comfortable communication in the community. 
Different speech means can be used to achieve compliance with these rules. The etiquette speech means, stereotypical for the network community and developed in its collective communicative practice, support and further develop it. Metalinguistic analysis aimed at the study of the range of various semiotic tools that contribute to the achievement of media speech communicative settings, and allows to identify these diverse means.

SE partly includes not only traditional means inherent in real communication, but also new ones, introduced into media:

- among traditional forms of etiquette there are customary etiquette words and formulas (pronominal-verbal forms of the 2 nd person, words of speech assessment, vocabulary of etiquette);

- among the new ones there are unconventional forms of address in the form of indeclinable nicks, separate types of texts (e.g., Posts "Request for advice", "Stimulation of emotional reactions", "Administrator's warning addressing the community"), speech reflexives. All these interacting means and methods allow to realize SE ideas in media-speech.

The "extension" of the dialogue structure to the media conditions is manifested in the change of the "grammar" of the design of the initiating replica that stimulates the movement of communication:

The "extension" of the dialogue structure to the media conditions is manifested in the change of the "grammar" of the initiating remark that stimulates the movement of communication:

1) the remark is unfolded gradually, in accordance with technical capabilities: in a special window, one specifies the topic, then the participant introduces himself $\sim$ herself (the nick appears immediately after clicking on the Comments button), next the special "fill in" box is filled with the initiating text;

2) acquaintance with communication participants, as a rule, has a formula representation "avatar + nick (nickname) + time and date of placement", where both the avatar and the nick are individualized;

3) a replica can be a "live" monologue or a "post", including a quote, or an image with a quote, or just an image;

4) posts can be different in purpose and style of expression: informative (for example, in professional or specialized communities), involving into discussion (in specialized communities), entertaining (in leisure communities);

5) in order to involve participants into communication, a special ethics and aesthetics of combining verbal and non-verbal is formed in initiating: welcome aphoristic nature, high emotiveness, polemics are praised;

6) iconic signs are widely used: emoticon consisting of icons, images "supporting" modality necessary for group communication - stimulating the speech activity - comments that demonstrate friendliness and fun;

7) among the socially approved forms of speech behavior in the community, participants mention wit, so comic expressing means are active, however, the use of this resource is not always successful; 
8) the youth audience of the community is characterized by shocking dismissive attitude to all norms: linguistic, communicative, ethical, aesthetic (so-called trash).

Verbal response situations often demonstrate the following courtesy means:

1) a response nature of the statement, addressing the initiator; when calling the initiator with the nick, the latter is not inclined,

2) the formula for the respondent's presentation is the same as the initiator's: "avatar+nickname+time and date of placement";

3 ) "connection" to the initiating replica, performed by repeating key words or combinations from the initiating replica,

4) deviation from the topic set by the initiator, because the communication is not face to face.

To improve the quality of communication, for the propaedeutics of aggressiveness in communication, different ways are used:

1) the administrator sets out communication rules in a special type of text where he/she warns of prohibitions concerning certain topics, restrictions on certain speech actions, and sanctions for violations of speech etiquette of the community;

2) the administrator sends a warning to individual "guilty" communicants;

3) participants maintain a distance in communication, using conventional abbreviations, highly specialized jargon, allowing to narrow the audience of communication, mark "their" people, distance "strangers" gently;

4) members of the group give an assessment of someone else's speech using special words that express a negative attitude to someone's statements: flood, ban, trolling, hyip, calling their authors - flooders, trolls, hypers, etc.

5) technical sanctions are imposed on violators of the rules: sending messages into ignore category, removing excessively rude comments.

\section{Conclusion}

Speech etiquette in the community is a resource that helps to create comfort in communication: to provide "communicative conveniences" to express the semantic position of each participant, to pay attention to each other, to preserve emotional comfort, to show courtesy, to neutralize aggression, and to prevent speech crimes. In each group there are internal rules of its existence helping to maintain harmonious interaction of Internet communities' members. In this kind of quasi-communication, a situation of contact initiation, maintaining, and reaction to a communicative provocation can be considered etiquette.

For the comfortable interaction, its own rules for the use of resources that support communication are established. These resources are diverse: standard constructions, organized by the combination of multilevel linguistic means, separate remarks inside the dialogic interaction, texts of a model structure, and meta-text containing an assessment of the communicants' verbal behavior. The combination of traditional and new tools forms a specific system - SE in virtual communities, which includes a variety of speech resources. The study showed the effectiveness 
of meta-linguistic analysis of online communication speech organization, which helps to identify not just individual tools and techniques of communication harmonization, but also their place in speech interaction.

One of the heuristic scientific approaches related to the study of audience behavior in Internet communication is the consideration of how speech etiquette varies in online communities. Its meta-linguistic analysis allows to establish the etiquette of the situation, use of verbal and non-verbal means and methods of their explication. The analysis reveals new forms and ways of organizing communities in the network. Such analysis should be supplemented with sociolinguistic research to see and explain the correlation between the social characteristics of the community members and the variability of the speech etiquette rules established within the communities. In general, the interdisciplinary linguistic analysis introduces social and cultural processes related to the mediatization of public consciousness into the field of public visibility. Summing up, we will highlight the most important issues for discussion aimed at clarifying the rules of communicative behavior that guide users of different social networks: 1 . What are the communicative values as understood by social media participants? 2. What are the communicative risks and threats to communicative security from the point of view of the researcher and from the point of view of the interaction participants? 3 . What speech protection measures against communication threats are taken by participants in different networks? 4 . What social characteristics of online communities audience can influence the formation of speech etiquette?

(C) Liliya Duskaeva, 2020
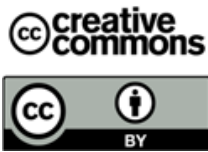

This work is licensed under a Creative Commons Attribution 4.0 International License https://creativecommons.org/licenses/by/4.0/

\section{Acknowledgements:}

The author is grateful to Julia Konyaeva and Victoria Vasilyeva, Associate Professors of the Media Linguistics Department, St. Petersburg State University, as well as to graduate student Camilla Pusurmanova who provided additional examples of speech etiquette resources use in online communities.

\section{REFERENCES}

Akishina, A. A. \& Formanovskaya, N. I. 1983. Russian speech etiquette. Moscow: Russian language. (In Russ.).

Alpatov, V. M. 2018. Politeness and etiquette (illustrated with Russian and Japanese material). Moscow: Political encyclopedia. (In Russ.).

Balakai, A. G. 2004. Explanatory dictionary of Russian speech etiquette. Moscow: Astrel'. (In Russ.).

Blum-Kulka, Shoshana. 1987. Indirectness and politeness in requests: Same or different? Journal of Pragmatics 11 (2). 131-146. 
Blum-Kulka, Shoshana \& Olshtain, Elite. 1984. Requests and Apologies: A Cross-Cultural Study of Speech Act Realization Patterns (CCSARP). Applied Linguistics 5. 196-213.

Boyd, Danah. 2006. Friends, friendsters and top 8: Writing community into being on social network sites. First Monday 11 (12).

Boyd, Danah \& Heer, Jeffrey. 2006. Profiles as conversation: Networked identity performance on friendster. In Proceedings of the Hawai'i International Conference on System Sciences (HICSS-39). Kauai, HI: IEEE Computer Society.

Brown, Penelope \& Levinson, Stephen. 1987. Politeness: Some Universal in Language Usage. Cambridge: Cambridge University Press.

Coulmas, Florian. 2005. Linguistic etiquette in Japanese society. In R. Watts, S. Ide \& K. Ehlich (eds.). Politeness in Language: Studies in its History. Theory and Practice, 299-323. Berlin/New York: Mouton de Gruyter.

Coulmas, Florian. 1981. "Poison to Your Soul”. Thanks and Apologies Contrastively Viewed. In F. Coulmas (ed.). Conversational Routine, 69-91. The Hague: Mouton.

Cubajevaite, Laura \& Ruzaite, Jurate. 2007. Apologies in Business Communication. Estonian Papers in Applied Linguistics 3. 67-81.

Goldin, B. E. 1983. Speech and etiquette. Moscow: Prosveshchenie. (In Russ.).

Goffman, Erving. 1974. Frame Analysis: An Essay on the Organization of Experience. Cambridge: Cambridge Univ. Press.

Grice, Herbert P. 1975. Logic and Conversation. In P. Cole \& J. L. Morgan (eds.). Semantics, 3, Speech Acts, 41-58. New York: Academic Press.

Duskaeva, L. R. 2018. Speech etiquette in media. In L. R. Duskaeva (ed.), Medialinguistics in concepts and terms. Dictionary-reference. Moscow: Flinta. (In Russ.).

Duskaeva, L. R. \& Prokofyeva, N. A. 2012. Etiquette speech genres in media discourse. Russian and foreign philology 3 (19). 177-186. (In Russ.).

Ermakova, O. I. 2000. Ethics in computer jargon. In N. D. Arutiunova (ed.), Logical analysis of language. Languages of ethics, 246-253. Moscow: Languages of Russian culture. (In Russ.).

Ferguson, Charles A. 1976. The Structure and Use of Politeness Formulas. Language in Society 5 (2). 137-151.

Formanovskaya, N. I. 2015. Russian speech etiquette: linguistic and methodological aspects. Moscow: URSS. (In Russ.).

Formanovskaya, N. I. 1989. Speech etiquette and culture of communication. Moscow: High school. (In Russ.).

Held, Georg. 2005. Politeness in linguistic research. In R. Watts, S. Ide \& K. Ehlich (eds.), Politeness in Language: Studies in its History, Theory and Practice, 131-154. Berlin/New York: Mouton de Gruyter.

Khrakovskiy, V. S. \& Volodin, A. P. 1986. Semantics and typology of the imperative. Russian imperative. Leningrad: Nauka. (In Russ.).

Kasper, Gabriele. 1990. Linguistic Politeness: Current research issues. Journal of Pragmatics 14 (2). 193-218.

Kerbrat-Orecchioni, Catherine. 2006. Politeness in small shops in France. Journal of Politeness Research. Language, Behaviour, Culture 2 (1). 79-103.

Konchakovskiy, R. V. 2010. Network Internet community as a socio-cultural phenomenon. $\mathrm{PhD}$ thesis. Ekaterinburg. (In Russ.).

Kostomarov, V. G. 1967. Russian speech etiquette. Russian language abroad 1. 56-62. (In Russ.).

Lacoff, Robin. 1973. The Logic of Politeness, or Minding Your P's and Q's. In Papers from the 9th Regional Meeting, Chicago Linguistic Society, 292-305. Chicago. 
Larina, Tatiana V. 2009. Category of politeness and communication style. Comparison of English and Russian linguistic and cultural traditions. Moscow: Languages of Slavic cultures. (In Russ.).

Larina, Tatiana. 2015. Culture- specific communicative styles as a framework for interpreting linguistic and cultural idiosyncrasies. International Review of Pragmatics 7 (5). 195-215.

Leech, Geoffrey N. 1983. Principles of Pragmatics. London: Longman.

Locher, Miriam. 2004. Power and politeness in Action. Disagreements in Oral Communication: Language, Power and Social Process. Berlin: Mouton de Gruyter.

Osetrova, E. V. 2015. Being an ethical speaker online: correspondence with foreign partners. Journal of Siberian Federal University. Series: Humanities 8 (11). 2561-2571. (In Russ.).

Pakhomova, I. N. 2008. New phenomena in Russian speech etiquette (by the material of mass media). PhD thesis abstract. Moscow. (In Russ.).

Pronkina, E. S. 2016. Modes of publicity and privacy in social media. Knowledge. Understanding. Skill 4. 315-319. (In Russ.).

Ratmair, Renate. 2009. "New Russian politeness" - fashion of business etiquette or radical pragmatic change? Linguistics issues 1.63-81. (In Russ.).

Risinzon, C. A. 2010. General and ethno-cultural in Russian and English speech etiquette. Saratov: Nauka Publishing center. (In Russ.).

Sergodeev, B. A. 2014. Communicative culture in online communities of modern Russian society. PhD thesis. Maikop. (In Russ.).

Sifianou, Maria. 1999. Politeness Phenomena in England and Greece: A Cross-cultural Perspective. New York: Oxford University Press Inc.

Tarasenko, T. V. 2002. Etiquette speech genres: experience of description (on the example of a congratulation genre description). Genres of the speech 3. 283-289. (In Russ.).

Article history:

Received: 10 June 2019

Revised: 15 August 2019

Accepted: 29 November 2019

\section{История статьи:}

Дата поступления в редакцию: 10 июня 2019

Дата принятия к печати: 29 ноября 2019

\section{Bionote:}

LILIYA DUSKAEVA is Dr. (Advanced Doctorate), Professor, Chair of the Department of Media Linguistics of School of Journalism and Communications of St.-Petersburg State University. Author of over 200 publications. Head of the Medialinguistic Commission of the International Committee of Slavists, member of the editorial board of the journals "Stylistics" (Opole, Poland) and "Tertium Linguistic Journal" (Krakow, Poland). Research interests: functional stylistics, media linguistics, pragmatics, language praxeology. Emeritus professor of Second Beijing Foreign Studies University.

\section{Contact information:}

E-mail:1.duskaeva@spbu.ru 
Сведения об авторе:

ДУСКАЕВА ЛИЛИЯ РАШИДОВНА - доктор филологических наук, профессор, зав. кафедрой медиалингвистики Высшей школы журналистики и массовой коммуникации Санкт-Петербургского государственного университета. Автор свыше 200 публикаций. Руководитель медиалингвистической комиссии при международном комитете славистов, член редколлегии журналов «Стилистика» (Ополе, Польша), «Tertium Linguistic Journal» (Краков, Польша) и др. Научные интересы: функциональная стилистика, медиалингвистика, прагматика, праксиология языка. Почетный профессор Второго Пекинского университета иностранных языков.

Контактная информация:

E-mail:1.duskaeva@spbu.ru 